\title{
Climatic and Economic Factors Affecting the Annual Supply of Wild Edible Mushrooms and Berries in Finland
}

\author{
Veera Tahvanainen ${ }^{1, *}$, Jari Miina ${ }^{2}\left(\mathbb{D}\right.$ and Mikko Kurttila ${ }^{2}$ \\ 1 Faculty of Science and Forestry, School of Forest Sciences, University of Eastern Finland (UEF), P.O. Box 111, \\ FI-80101 Joensuu, Finland \\ 2 Natural Resources Institute Finland (Luke), Yliopistokatu 6B, FI-80100 Joensuu, Finland; \\ jari.miina@luke.fi (J.M.); mikko.kurttila@luke.fi (M.K.) \\ * Correspondence: veera.tahvanainen@uef.fi; Tel.: +358-29-532-4106
}

Received: 11 April 2019; Accepted: 27 April 2019; Published: 30 April 2019

\begin{abstract}
Finnish non-timber forest products (NTFPs) are valued on the national and international markets. Yet, the annual marketed quantities vary considerably, causing instability in supply chains. Thus, climatic and economic factors affecting the annually aggregated supply of top-marketed mushrooms (ceps, milk caps, and chanterelle) and berries (bilberry, cowberry, and cloudberry) in Finland were studied. Data on mushroom and berry market prices $(€ / \mathrm{kg})$ and quantities $(\mathrm{kg})$ were obtained from the statistics on annual quantities of berries and mushrooms bought by organized trade and industry in Finland (1978-2016). The species-specific supply functions were described as linear regression models, where annually aggregated quantities were predicted as a function of climatic and economic variables. Our results suggested that climatic variables influenced the marketed quantities of NTFPs through the biological yields of berries and mushrooms, and that the market price had a negative effect on the marketed quantities of ceps, milk caps, and berries. The markets for NTFPs have become more international at the second half of the study period (1999-2016), modifying the price-quantity relationships of ceps, milk caps and cloudberries. Additionally, the number of visas issued to Thai pickers increased the marketed quantities of bilberries and cowberries.
\end{abstract}

Keywords: non-timber forest products; forest berries; wild edible fungi; Vaccinium myrtillus; Vaccinium vitis-idaea; Rubus chamaemorus; Boletus edulis; Lactarius spp.; Chantharellus cibarius

\section{Introduction}

The wild forest mushroom and berry markets are well known in Finland [1] and elsewhere in Europe [2,3]. Ceps (Boletus edulis Bull., B. pinophilus Pilát \& Dermek) are respected worldwide, and their export markets are notable in Finland [1,4], whereas milk caps (Lactarius trivialis Fr., L. rufus (Scop.) Fr., L. torminosus (Schaeff.) Pers.) and chanterelles (Cantharellus cibarius Fr.) are mainly exchanged on domestic markets [4]. The most common berry species on the Finnish markets are bilberry (Vaccinium myrtillus L.) and cowberry (Vaccinium vitis-idaea L.) [4,5], which are also internationally renowned berry species [1]; annually, large frozen amounts, up to a few million $\mathrm{kg}$, are exported to Asian markets [4]. In the northern European countries, cloudberry (Rubus chamaemorus L.) is highly valued $[3,4]$. Even though the mushroom and berry markets are considerable, the marketed quantities dramatically vary between years, causing instability in the supply chains $[5,6]$. Determining the factors that affect such annual variation is important and would promote a more stable supply chain of mushrooms and berries.

The between-year and -site variations in berry [7,8] and mushroom [9] yields are enormous. The stand variables affect the yields available for picking berries $[7,8,10]$ and mushrooms $[9,11,12]$. 
They are not, however, suitable for predicting the annual variation in the yields of berries and mushrooms, which are more affected by climatic factors. Based on previous studies, climatic variables explained some of the between-year variation in berry $[13,14]$ and mushroom yields [15-17]. For example, in a French study, the annual mean temperature was used to explain the distribution and abundance of $V$. myrtillus [14]. Similarly, in a Spanish study, temperature and precipitation influenced the production of B. edulis and L. group deliciosus in Pinus sylvestris L. stands [11]. It is obvious that the annual amounts of berries and mushrooms entering the markets depend on their annual yields, and, thus, also on the annual climatic conditions. For example, precipitation and temperature affect the amounts of mushrooms harvested and offered for sale in Spain $[18,19]$.

The biological yields have a clear effect on the quantities picked for sale and for household consumption, yet it is estimated that, at most, less than $10 \%$ of the biological yield of berries, and even less of that of mushrooms, are harvested annually [20,21]. The biological yield, however, is not the only factor causing variations in marketed quantities [18]. Economic factors can be assumed to have an impact on the marketed quantities of mushrooms and berries. When climatic and economic factors were used to predict the supply of mushrooms on domestic markets in Spain, the price of Lactarius deliciosus (L.) Gray had a positive relationship with the supply $[18,19]$. This is not surprising, considering that the phenomenon follows the general principles of supply, where the higher (lower) the selling price, the higher (lower) the quantities on the market [22,23]. On the contrary, in a Finnish study, the price paid to cowberry pickers was negatively correlated with the quantities traded on the organized domestic markets, and a similar relationship has been observed for bilberry [5]. When the demand for milk caps was studied, there was an inverse relationship between the price and the quantity in saffron milk cap on the market in Spain [24].

Most of the berries and mushrooms, particularly bilberries and ceps, are exported from Finland fresh and frozen. This means that the extent of the value added is often low, whereas the competition on the international markets is high [1]. Although berries and mushrooms have been harvested and sold in almost similar ways since the 1970s, some changes have occurred, considering, for example, the internationalization of markets. International trade has increased dramatically since the 1990s, influencing the marketed quantities of some non-timber forest products (NTFPs). The markets of mushrooms are mainly dominated by ceps, which are sold to southern Europe. Finland joined the EU in 1995 and, soon after, the Economic and Monetary Union (EMU), which meant that the rates of the member states' currencies were irrevocably fixed in 1999 before implementing a common currency [25]. Later, the enlargement of the EU to eastern European countries in 2004 and 2007 further increased the competition on the markets of wild edible berries and mushrooms.

In Finland, commercial berry picking is primarily done by foreign pickers, mainly from Thailand, but also from a few eastern European countries. Also, Finnish people generally pick large quantities of forest berries: it is estimated that about 42 million $\mathrm{kg}$ are picked annually, but mostly for household use [1]. Mushroom markets are not as extensive as those for berries [4]. Most of the mushrooms are picked by domestic pickers and exported fresh and frozen to Europe [1]. The variation in annual quantities of berries on the market is smaller than that of mushrooms. In addition, berries are picked for sale throughout the country, whereas mushroom collection takes mainly place in eastern Finland [4].

The factors affecting the supply of wild edible berries and mushrooms have hardly been studied $[18,24,26]$, particularly in Finland. Rather much is already known on the biological yields, production, and harvesting of NTFPs, in particular wild edible mushrooms and berries. However, this topic is gradually gaining more attention, as the demand for NTFPs is growing. Knowing the factors affecting the quantities of marketed berries and mushrooms would be beneficial for businesses and provide information on the most important barriers of NTFP markets.

\section{Aim and Hypotheses}

Our aim was to study the climatic and economic factors that affect the annually aggregated supply of non-timber forest products (NTFPs) in Finland. The objective was to see if variables other 
than climatic ones explain the variation in annually marketed quantities on Finnish NTFP markets. In particular, we wanted to investigate how suppliers, i.e., NTFP pickers, react to changes in market prices at a given biological NTFP yield. The statistics on annual quantities and market prices of wild edible forest berries and mushrooms bought by organized trade and industry in Finland were used as study materials. The most commercially used mushroom species, i.e., ceps (Boletus edulis, B. pinophilus), milk caps (Lactarius trivialis, L. rufus, L. torminosus) and chanterelles (Chantarellus cibarius) as well as berry species, i.e., bilberries (Vaccinium myrtillus), cowberries (Vaccinium vitis-idaea), and cloudberries (Rubus chamaemorus), were included in our analyses. We tested the following hypotheses:

(1) Climatic factors affect the annual yields of berries and mushrooms and, hence, also explain the annual quantities of marketed berries and mushrooms.

(2) (Market prices affect the quantities of berries and mushrooms entering the markets, according to the general law of supply.

(3) The globalization of markets, due to joining the EU and irrevocably fixing the exchange rates of the member states' currencies in the Economic and Monetary Union (EMU), has an impact on the relationship between the market prices and the quantities of mushrooms and berries, particularly ceps and bilberries, which are traded on international markets.

(4) The annual number of visas issued for Thai pickers influence the quantities of the berries entering the markets.

\section{Materials and Methods}

\subsection{Mushroom and Berry Markets}

Annual data on mushroom and berry market prices $(€ / \mathrm{kg})$ and quantities $(\mathrm{kg})$ were obtained from the statistics on the annual quantities of berries and mushrooms bought by organized trade and industry in Finland, the so-called "MARSI-statistics" [4]. This information included the quantities and prices of the most common berry and mushroom species, such as bilberry (Vaccinium myrtillus), cowberry (Vaccinium vitis-idaea), cloudberry (Rubus chamaemorus), ceps (Boletus edulis, B. pinophilus), milk caps (Lactarius trivialis, L. rufus, L. torminosus) and chanterelle (Chantarellus cibarius). For mushrooms, the statistics on market prices and quantities were obtained from eastern Finland only because mushroom collection mainly takes place in that area [4]. The statistics were based on annual inquiries to the companies in wild berry and mushroom markets and did not include direct trade to hotels, restaurants, and market places. The annual deflated prices and quantities of these mushrooms and berries in 1978-2016 are presented in Figures 1 and 2. The producer price indices were used to deflate the prices $(1949=100)$. The correlations among the deflated prices and quantities are given in Table 1 .

Table 1. Correlation among the annual quantities (above the diagonal) and deflated prices (below the diagonal) of mushrooms and berries bought by organized trade and industry (correlation between quantity and price are shown as bold on the diagonal), as well as correlations between the annual quantities and monthly precipitation sums and the annual numbers of Thai visas $(n=39)$.

\begin{tabular}{|c|c|c|c|c|c|c|}
\hline & Ceps & Milk Caps & Chanterelle & Bilberry & Cowberry & Cloudberry \\
\hline Ceps & $-0.35 *$ & 0.05 & 0.16 & $-0.40 *$ & $-0.34 *$ & 0.24 \\
\hline Milk caps & -0.16 & -0.10 & -0.08 & -0.22 & -0.16 & -0.15 \\
\hline Chanterelle & -0.18 & 0.02 & -0.27 & $-0.36^{*}$ & -0.27 & 0.12 \\
\hline Bilberry & -0.27 & -0.10 & 0.19 & $-0.38 *$ & $-0.38 *$ & -0.08 \\
\hline Cowberry & $-0.40 *$ & 0.05 & 0.26 & $-0.43^{* *}$ & $-0.37 *$ & 0.13 \\
\hline Cloudberry & -0.11 & -0.06 & 0.00 & 0.01 & -0.23 & -0.25 \\
\hline Precipitation in April & -0.12 & 0.07 & -0.09 & $0.33 *$ & 0.35 * & 0.17 \\
\hline Precipitation in May & 0.16 & -0.14 & -0.09 & $0.42 * *$ & 0.10 & -0.09 \\
\hline Precipitation in June & 0.05 & -0.24 & 0.30 & -0.07 & -0.03 & $-0.33^{*}$ \\
\hline Precipitation in July & -0.12 & 0.13 & $0.53^{* *}$ & 0.05 & -0.01 & 0.03 \\
\hline Precipitation in August & $0.39 *$ & 0.28 & $0.38 *$ & -0.00 & 0.11 & -0.12 \\
\hline Thai visas & 0.26 & $-0.48^{* *}$ & -0.00 & $0.76^{* *}$ & $0.52 * *$ & $-0.36^{*}$ \\
\hline
\end{tabular}



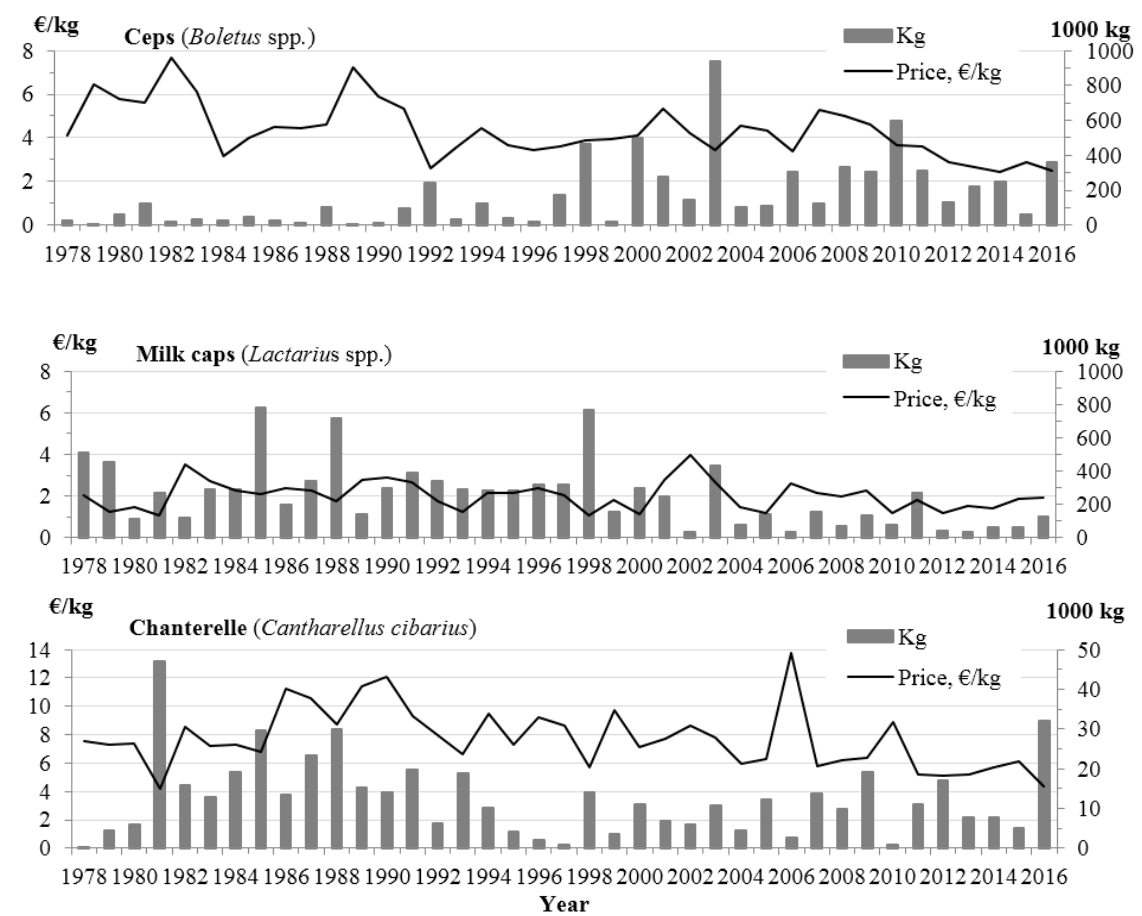

Figure 1. Quantities (1000 kg/a) and deflated prices $(€ / \mathrm{kg})$ of ceps, milk caps, and chanterelles bought by organized trade and industry in eastern Finland during 1978-2016. Note: Y-axis scales are different.
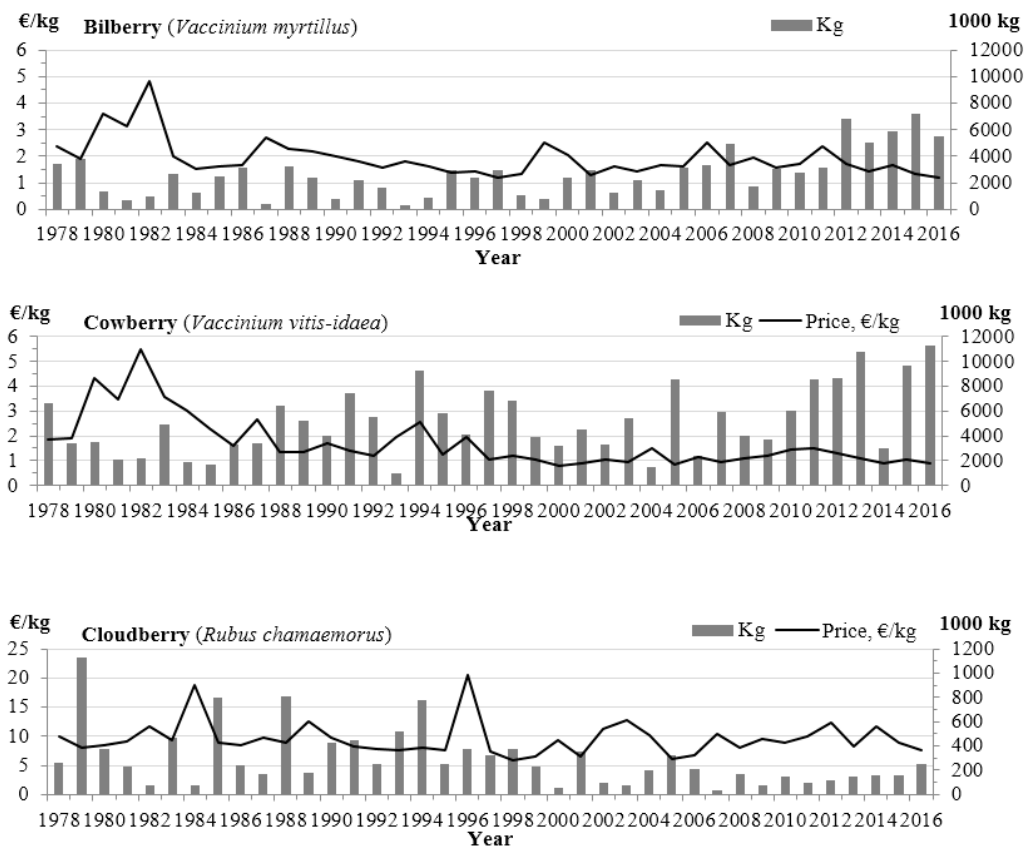

Figure 2. Quantities (1000 kg/a) and deflated prices ( $€ / \mathrm{kg})$ of bilberries, cowberries, and cloudberries bought by organized trade and industry in Finland during 1978-2016. Note: Y-axis scales are different.

The software package EUROSTAT statistics was used to include variables of international trade for the species B. edulis. The statistics of B. edulis trade included imported monthly quantities of fresh and chilled B. edulis from Finland to Italy during 1999-2016 [27]. One of the largest changes in berry markets was the introduction of foreign pickers since 2005, and, hence, the annual numbers of visas for Thai berry pickers were included in the analyses. The numbers of Thai visas were derived from the Ministry of Foreign Affairs of Finland and from articles on foreign berry pickers in Finland [28-30]. 


\subsection{Climatic Variables}

Data on annual climatic variables were obtained from a Finnish gridded dataset that consisted of daily climatic variables from the Finnish meteorological Institute observations interpolated from a $10 \mathrm{~km} \times 10 \mathrm{~km}$ grid [31]. In this study, the climatic variables of a grid $\left(62^{\circ} 34^{\prime} \mathrm{N}, 30^{\circ} 01^{\prime} \mathrm{E}\right)$ close to Joensuu in eastern Finland were used. The variables considered that affected the annual yields and, thus, the supply of berries and mushrooms during the years 1978-2016 were: monthly precipitation sums, monthly mean temperatures, effective temperature sum (threshold value $+5^{\circ} \mathrm{C}$ ), and minimum and maximum daily temperatures of the current and previous years.

\subsection{Modelling the Supply}

In our study, analyses included only the supply side of the market for wild edible mushrooms and berries. It would have been interesting to analyse both the supply and demand of the NTFP market, but relevant data were not available for analysing the demands for wild mushrooms or berries at the Finland or at the EU level.

The supply function was described as a linear regression model, where the dependent variable was the quantity of mushrooms or berries bought by organised trade and industry (Table 2). Climatic and economic variables were used as independent variables. The error terms were assumed to arise from a first-order autoregressive process.

Table 2. Mean, range, and standard deviation of annual quantities $(1000 \mathrm{~kg})$ and deflated prices $(€ / \mathrm{kg})$ of mushrooms bought by organised trade and industry in eastern Finland and berries in Finland, and the main climatic variables affecting mushroom and berry yields during 1978-2016 $(n=39)$. Mean, range, and standard deviation of the annual number of Thai visas are presented for the years 2005-2016 $(n=12)$; prior to that, the number of visas was zero.

\begin{tabular}{cccccc}
\hline Variable & & Mean & Minimum & Maximum & Std. Dev. \\
\hline & Ceps & 174.6 & 6.6 & 941.4 & 196.5 \\
& Milk caps & 255.3 & 30.6 & 778.3 & 193.1 \\
Quantity $(1000 \mathrm{~kg})$ of & Chanterelle & 12.6 & 0.4 & 47.1 & 9.9 \\
& Bilberry & 2674.4 & 260.0 & 7199.8 & 1708.7 \\
& Cowberry & 5136.0 & 972.5 & $11,240.3$ & 2674.8 \\
& Cloudberry & 293.9 & 37.2 & 1128.1 & 238.8 \\
\hline \multirow{5}{*}{ Price $(€ / \mathrm{kg})$ of } & Ceps & 4.3 & 2.4 & 7.7 & 1.3 \\
& Milk caps & 2.0 & 1.1 & 4.0 & 0.7 \\
& Chanterelle & 7.7 & 4.2 & 13.8 & 2.2 \\
& Bilberry & 1.9 & 1.2 & 4.9 & 0.7 \\
& Cowberry & 1.7 & 0.8 & 5.5 & 1.0 \\
& Cloudberry & 9.5 & 5.8 & 20.6 & 3.0 \\
\hline \multirow{3}{*}{ Monthly total } & April & 28.3 & 3 & 66 & 15.5 \\
& May & 40.5 & 1 & 104 & 23.2 \\
& June & 64.3 & 23 & 131 & 26.4 \\
& July & 69.4 & 26 & 126 & 29.5 \\
& August & 76.0 & 18 & 171 & 33.7 \\
\hline Number of & Thai visas & 2331 & 92 & 3901 & 1145 \\
\hline
\end{tabular}

The linear regression models prepared for the supply of mushrooms and berries can be expressed as follows:

$$
\ln \left(y_{\mathrm{t}}\right)=\beta_{0}+\beta_{1} \cdot x_{1}+\beta_{2} \cdot x_{2}+\cdots+\beta_{\mathrm{n}} \cdot x_{\mathrm{n}}+v_{\mathrm{t}}
$$

where $y_{\mathrm{t}}$ is the quantity of berries (million $\mathrm{kg} /$ year) or mushrooms (1000 kg/year) bought by organised trade and industry in year $\mathrm{t} ; \beta_{0}, \beta_{1}, \ldots, \beta_{\mathrm{n}}$ are regression coefficients; $x_{1}, x_{2}, \ldots, x_{n}$ are predictors (i.e., climatic and economic variables); $v_{\mathrm{t}}=\rho \cdot v_{t-1}+e_{t}$ is the autocorrelated error term in year $\mathrm{t}$, $\mathrm{e}_{\mathrm{t}} \sim \operatorname{Nid}\left(0, \sigma_{\mathrm{e}}^{2}\right), \sigma_{\mathrm{v}}^{2}=\sigma_{\mathrm{e}}^{2} /\left(1-\rho^{2}\right)$, and $\rho$ is the autocorrelation coefficient. 
Both climatic and economic factors were used as predictors in the supply models. Favourable climatic conditions increase the biological yields of wild mushrooms [9] and berries [32,33]. Thus, it was hypothesised that climatic variables, especially precipitation during the growing season, which varies considerably from year to year, would explain the variation in biological yields and, consequently, have a significant effect on the annual quantities of berries and mushrooms supplied to organised trade and industry in Finland. It was expected that if prices increase, mushroom and berry supply will also increase when all other factors (such as biological yields) are held constant. Due to the globalisation of markets, the effect of price on the supply of mushrooms and berries may have changed in the second half of the study period (1999-2016), which was also considered when model predictors were selected. In addition, the supply function of globally marketed NTFPs (e.g., ceps, of which almost $90 \%$ are exported) was expected to be different from that of locally marketed NTFPs (e.g., cloudberry). Also, the introduction of foreign pickers to berry markets in 2005 was assumed to affect the supply function of wild berries, but not that of mushrooms.

The performance of the supply models was evaluated by examining the magnitude and distribution of the residuals as a function of the predictions as well as the predictors of the model. The aim was to detect any obvious dependencies or patterns that indicated systematic discrepancies. The log-transformed quantities were back-transformed to the original scale before the error statistics were calculated. Snowdon's bias correction factor [34] was used to correct the bias caused by the logarithmic transformation. The accuracy of the model predictions was determined by calculating the proportion of the explained variance $\left(R^{2}=1-\right.$ (unexplained variation/total variation)) and precision, i.e., root mean square error (RMSE). The relative root mean square error (RMSE\%) was calculated by dividing the RMSE by the mean of the predicted quantity.

\section{Results}

\subsection{Supply of Wild Edible Mushrooms}

The annual quantities of three wild edible mushroom species bought by organizsed trade and industry in eastern Finland were modelled using climatic and economic variables (Table 3). According to the models, the precipitation in August positively and significantly influenced the marketed quantities of ceps and milk caps, while the total precipitation in June and July influenced that of chanterelles. The results corresponded to the harvesting seasons (months) of these mushroom species.

Table 3. Coefficients of the supply models for the annual quantities of ceps, milk caps, and chanterelles $(1000 \mathrm{~kg})$ bought by organised trade and industry in eastern Finland (Equation (1)). The data covered the years 1978-2016, with a total number of observations of 39.

\begin{tabular}{|c|c|c|c|c|}
\hline & Variable & Ceps & Milk Caps & Chanterelle \\
\hline$\beta_{0}$ & Intercept & $4.8329 * * *$ & $4.9926^{* * *}$ & $2.8160^{* * *}$ \\
\hline$\beta_{1}$ & Precipitation in June and July (mm) & - & - & $0.0058 * *$ \\
\hline$\beta_{2}$ & Precipitation in August (mm) & $0.0087 *$ & $0.0064 *$ & - \\
\hline$\beta_{3}$ & Price $(€ / \mathrm{kg})$ & $-0.3598^{* *}$ & 0.0886 & $-0.1775^{* *}$ \\
\hline$\beta_{4}$ & Dummy ${ }^{1} \bullet$ Price $(€ / k g)$ & $0.3158^{* * *}$ & $-0.4811^{* * *}$ & -0.0479 \\
\hline$\sigma_{v}^{2}$ & Error variance & 0.8686 & 0.5050 & 1.1131 \\
\hline$\rho$ & Autocorrelation coefficient & -0.0023 & 0.1380 & $0.6015^{* * *}$ \\
\hline & Log likelihood & -58.9 & -47.5 & -55.9 \\
\hline & Snowdon's bias correction ratio & 1.3618 & 1.1948 & 1.3667 \\
\hline & $R^{2}(\%)$ & 53.9 & 32.5 & 34.6 \\
\hline & RMSE (1000 kg/year) & 133.5 & 158.7 & 8.0 \\
\hline & RMSE\% $(\%)$ & 76.5 & 62.2 & 63.5 \\
\hline
\end{tabular}

\footnotetext{
$*^{*}, * *$ and ${ }^{* * *}$ : significant at the $0.1,0.05$ and 0.01 level, respectively. ${ }^{1}$ Dummy $=1$ in 1999-2016, otherwise dummy $=0$.
} 
The effect of price was, surprisingly, negative and statistically significant on the supply of ceps and chanterelles. Due to the internationalisation of markets in the late 1990s (Dummy), the effect of price on the annual quantities of marketed ceps turned out to diminish, and for chanterelle, the effect of price on annual quantities turned out to be even more negative. For the milk caps, the effect of price was not statistically significant during the years 1978-1998, but turned out to be negative and statistically significant during the remaining study period from 1999-2016.

Depending on the species, the climatic and economic variables explained $33 \%-54 \%$ of the variation in annual marketed quantities of mushrooms. The first-order autocorrelation of the residuals was statistically significant and positive in the model only for chanterelles. The relative RMSEs of the models were $62 \%-77 \%$.

\subsection{Supply of Wild Edible Berries}

The supply model was fitted for three wild edible berry species in Finland using climatic and economic variables (Table 4). Precipitation in April increased the marketed quantities of bilberries and cowberries, but for cowberries, the effect of climatic factors was not statistically significant. The effect of price on bilberry and cowberry yields was negative and statistically significant. In the models for bilberry and cowberry, the variable Dummy for internationalisation was not statistically significant, but for cowberry, internationalisation strengthened the negative effect of price.

Table 4. Coefficients of the supply models for the annual quantities of bilberries, cowberries, and cloudberries (million $\mathrm{kg}$ ) bought by organised trade and industry in Finland (Equation (1)). The data covered the years 1978-2016, with a total number of observations of 39.

\begin{tabular}{|c|c|c|c|c|}
\hline & & Bilberry & Cowberry & Cloudberry \\
\hline$\beta_{0}$ & Intercept & $0.7879 * *$ & $1.5995 * * *$ & $0.0331^{* * *}$ \\
\hline$\beta_{1}$ & Precipitation in April (mm) & $0.0012 *$ & 0.0082 & - \\
\hline$\beta_{2}$ & Precipitation in June (mm) & - & - & $-0.0072 * *$ \\
\hline$\beta_{3}$ & Price $(€ / \mathrm{kg})$ & $-0.3138^{* *}$ & $-0.2068^{* *}$ & $-0.0732 * *$ \\
\hline$\beta_{4}$ & Dummy ${ }^{1} \bullet$ Price $(€ / k g)$ & 0.0729 & -0.2750 & $-0.0961^{* * *}$ \\
\hline$\beta_{5}$ & Thai visas (1000 pcs/year) & 0.2474 * & $0.2036 * *$ & 0.0317 \\
\hline$\sigma_{\tau 1}^{2}$ & Error variance & 0.3593 & 0.2355 & 0.3091 \\
\hline$\rho$ & Autocorrelation coefficient & 0.2065 & -0.0806 & -0.3055 * \\
\hline & Log likelihood & -41.0 & -34.9 & -42.4 \\
\hline & vdon's bias correction ratio & 1.0845 & 1.0935 & 1.1544 \\
\hline & $R^{2}(\%)$ & 54.9 & 40.4 & 42.3 \\
\hline & RMSE (mill. kg/year) & 1.1 & 2.1 & 0.2 \\
\hline & RMSE\% (\%) & 42.9 & 40.2 & 61.7 \\
\hline
\end{tabular}

*** and ${ }^{* * *}$ : significant at the $0.1,0.05$ and 0.01 level, respectively. ${ }^{1}$ Dummy $=1$ in 1999-2016, otherwise dummy $=0$.

The number of Thai pickers increased the marketed quantities of bilberries and cowberries, so that an increase of pickers by 1000 meant, on average, a $28 \%$ increase in the marketed bilberry quantity and a $23 \%$ increase in the marketed cowberry quantity.

The marketed quantities of cloudberries were negatively influenced by precipitation in June and by the price. The negative effect of price strengthened significantly after 1998. The number of Thai pickers had a non-significant effect on the marketed quantities of cloudberries.

The climatic and economic variables explained $40 \%-55 \%$ of the variation in annual marketed quantities of berries. The relative RMSEs of the models for berries $(40 \%-62 \%)$ were slightly lower than those for mushrooms. The autocorrelation coefficient was statistically significant only for cloudberry. 


\section{Discussion}

\subsection{Climatic Factors}

As hypothesised, climatic variables influenced the marketed quantities of NTFPs because the biological yields have a direct effect on the harvestable crops. According to the results, the total precipitation in August had a positive impact on the quantities of ceps and milk caps, and the total precipitation in June and July positively impacted chanterelle amounts entering the markets. This is in line with the previous findings that a high precipitation improved the biological yields of marketed mushrooms $[9,15,16,35]$. Similarly, mushroom picking frequency could have decreased in years with a poor crop [36]. In addition, it is possible that the weather conditions can also affect the picking activity. However, this mainly applies to mushroom picking for household consumption.

The effects of climatic variables on marketed berry quantities were more complex to interpret, since the berry crops are also affected by the availability of pollinators in the flowering periods and the weather conditions in the ripening periods of the berries [37]. Monthly aggregated mean temperatures and precipitation sums may not be able to adequately describe the effects of weather conditions on flowering, pollination, and ripening of berries. The precipitation sum in June had a negative effect on the marketed quantities of cloudberries, whereas the precipitation sums in April had a positive effect on the marketed quantities of bilberries (and cowberries, even if non-significant). Cloudberry flowers in June, and heavy and intense rainfall during the flowering period greatly affects the yield by irreversibly damaging the flowers. Also, the activity of pollinators is curbed by cool, rainy, and windy weather conditions, which would lead to unsuccessful pollination. Because precipitation in April will most likely come in the form of snow, the positive effect of April precipitation on bilberry (and cowberry) may be the result of postponed flowering; flowering later will decrease the risk of spring frost damage. However, in a study by Wallenius [33], the climatic factors before the flowering season had no effect on the yields of bilberries or cloudberries.

A study by Teräs [38] showed that weather conditions affect pollination in the flowering season, which, for bilberry, is during May and June and, for cowberry, during June and July. Also, according to Raatikainen [39], precipitation (rain) during the flowering season disturbs the pollination of the flowers of cowberries. In a Canadian study on lowbush blueberry (Vaccinium angustifolium Ait. and $V$. myrtilloides Michx.), the early summer rain during the flowering season decreased the yield due to decreased pollination [40]. The flowering season is sensitive to frost and pollination failures, especially in the cases of bilberry and cloudberry, whose flowering season is earlier than that of cowberry.

We found that the previous year's supplies did not significantly explain the following year's supplies, which is in line with the results of Wallenius [33], i.e., one year's abundant berry yield did not negatively affect the following year's yields. However, the significant first-order autocorrelation coefficients, positive for chanterelle and negative for cloudberry, implied that the climatic and economic factors were not able to describe the between-year variation in the quantities supplied, and that some predictors are still missing.

The limitations of the current study were that the climatic data were obtained only from the eastern part of the country, but the statistics on berries covered the entire country. In addition, cloudberries are mainly picked from the northern part of Finland [4].

\subsection{Effect of Price on Quantities of Marketed Mushrooms and Berries}

According to the models, the price paid to pickers had a negative effect on the quantities of ceps, milk caps, and berries entering the markets. This is surprising as, generally, the increasing price would also increase the quantity supplied [22,26]. Kangas [5] found also that when the domestic demand for cowberries was high, the price was low. In earlier studies in Spain, the quantities of marketed mushrooms increased when the price paid to pickers increased $[18,19,24]$. We interpreted our result as implying that the price paid to pickers was lower in the years when there were a lot of mushrooms and berries to pick, i.e., the biological yield was high. In good crop years, the labour output in picking 
( $\mathrm{kg} /$ hour) was higher than that in poor ones, and, thus, we assumed that pickers were willing to pick and sell mushrooms and berries at lower prices. If the crops were poor, the wholesalers had to pay higher prices to get mushrooms and berries to the markets.

Only in the model for milk caps, the price did not affect the marketed quantities. This may be due to the picking practice: milk caps and ceps are fruiting and being picked at the same time, but ceps are the main interest in mushroom picking as they obtain higher prices per $\mathrm{kg}$.

Using the annually aggregated statistics on the marketed quantities and market prices, we were not able to examine, for example, the seasonal patterns in the relationship between price and supply. Alfranca et al. [18] used weekly data on climatic and economic variables to capture the short-term disturbances in the markets of wild edible mushrooms in Spain. Consequently, they were able to study, for example, the behaviour of pickers when the price of mushrooms increased.

In Finland, ceps have three quality classes, which all have different prices. Seasonal conditions affect how the marketed quantities of ceps are distributed by quality classes, and, consequently, the annual price of ceps will be affected. More detailed information on weekly or monthly prices and supply by quality classes would have improved the modelling of cep supply. Unfortunately, these kinds of statistics are difficult to obtain, as it would require data collection at the wholesale level.

\subsection{The Globalising Markets}

The NTFP markets have been globalising since the late 1990s, and this has also affected the Finnish NTFP markets. The joining of the new member states into the European Union has increased the supply of NTFPs to EU countries where NTFPs are consumed in large quantities. Therefore, the competition in the mushroom and berry markets has increased.

Our results suggested that, due to the globalisation of the markets, the effect of price on the marketed quantities of ceps has decreased in Finland. High-competition markets for ceps are mainly located in southern Europe, and, therefore, it is logical that the price effect has decreased, since the price of ceps is no longer determined in Finland, but instead elsewhere in Europe. The price effect on marketed milk cap quantities was also strongly affected by globalisation, with a negative relationship with price. Marketed quantities of chanterelles were not affected by globalisation, since its markets are principally domestic. Chanterelles are also imported from Baltic countries, but mainly prior to the main season in Finland.

The price effects on bilberry and cowberry quantities were not affected by globalisation. Most probably, due to increasing global demands for bilberries and cowberries, similar changes as those for ceps were not observed in the relationship between price and quantities. The negative price effect on the marketed quantities of cloudberries has strengthened since 1999. This result is surprising because its markets are mainly domestic, although the Finnish food industry also imports cloudberries [4]. However, this result may be arbitrary or caused by unknown factors because the supply of cloudberries has dramatically decreased during the 2000s, but the price has been unaffected (Figure 2).

\subsection{Annual Number of Visas Issued for Thai Pickers}

A total of $75 \%$ of the berries picked for sale were picked by foreign pickers [4]. As we assumed, the number of visas issued for Thai pickers in each year increased the marketed quantities of bilberries and cowberries. This pattern was not observed for the supply model for cloudberry; still, a lot of the marketed cloudberries are picked by domestic pickers. Cloudberries are only picked by foreign pickers if the picking season is not overlapping with that of bilberries [41]. In Finland, the lack of commercial pickers has been discussed for decades, and to tackle this issue, pickers from Thailand were introduced in 2005. After this the picked amounts have increased, but discussion on ethical issues regarding foreign labor and boundaries of everyman's rights has been limiting the acceptability of commercial picking. [29,42]. 


\section{Conclusions}

The effects of climatic and economic factors on the annually aggregated supply of wild edible mushrooms and berries were studied using the statistics on annual marketed quantities and market prices of wild forest berries and mushrooms bought by organised trade and industry in Finland. Knowledge of the behaviour of NTFP markets would promote a more stable supply chain of mushrooms and berries in Finland.

As assumed, climatic factors affected the supply of mushrooms and berries. The precipitation during the yield season had a positive effect on the marketed quantities of mushrooms. The effects of climatic factors on the marketed quantities of berries were difficult to explain, mainly because these factors affected the yields in different ways during different stages of berry development. However, our results indicated that climatic factors controlled the berry yields and their marketed quantities by affecting the success of flowering and pollination. Also, the economic factors influenced the marketed berry and mushroom quantities. The effect of price on marketed quantities of ceps, milk caps, and berries was negative. We assumed that when the biological yield was high, the wholesalers pay lower price to the pickers. The NTFP markets have been globalising since the late 1990s, which has also affected the Finnish NTFP markets in different ways: the effect of price on the marketed quantities of ceps has diminished, the price-quantity relationship of milk caps became negative, and the negative price effect in case of cloudberries was strengthened. The results suggested that, after the market opening, the prices of some NTFPs are fixed by the European supply rather than by the national supply. The marketed quantities of bilberries and cowberries were positively influenced by the number of visas issued annually for Thai pickers.

The modelling demonstrated the complexity of the phenomena influencing the supply of wild edible mushrooms and berries. The supply of NTFPs is evidently influenced by several factors, and their mutual effects were not included in our analyses. For example, the fit of the supply models could be improved by also considering the effect of NTFP storage in good crop years as well as the quantities and prices of exported NTFPs. Also, the climatic data and market statistics obtained from the same region in Finland should be used in the future modelling.

Author Contributions: V.T., J.M. and M.K. designed the study; V.T. collected and analysed the data and wrote the paper; V.T., J.M., and M.K. discussed the results and contributed to the final manuscript.

Acknowledgments: This study was partly supported by the project Multiple Forest Use and Ecosystem Services, executed by the Natural Resources Institute Finland (Luke) and University of Eastern Finland, Doctoral programme: Forests and Bioresources (FORES).

Conflicts of Interest: The authors declare no conflict of interest.

\section{References}

1. Ristioja, A. Toimialaraportti: Luonnontuoteala; Työ- ja elinkeinoministeriö: Helsinki, Finland, 2017; p. 79.

2. Wong, J.L.G.; Prokofieva, I. Report Presenting Synthesis of Regional Sectoral Reviews to Describe the "State of the European NWFP". StarTree deliverable D1.3.2014. p. 96. Available online: https://star-tree.eu/images/ deliverables/WP1/D1_3_SOSR_nov2015.pdf (accessed on 11 March 2019).

3. Turtiainen, M.; Nuutinen, T. Evaluation of information on wild berry and mushroom markets in European countries. Small-Scale For. 2012, 11, 131-145. [CrossRef]

4. MARSI. Luonnonmarjojen ja -sienten kauppaantulomäärät vuonna 2016. Raportteja ja Selvityksiä 2017, 4, 55.

5. Kangas, K. Trade of main wild berries in Finland. Silva Fenn. 1999, 33, 159-168. [CrossRef]

6. Cai, M.; Pettenella, D.; Vidale, E. Income generation from wild mushrooms in marginal rural areas. For. Policy Econ. 2011, 13, 221-226. [CrossRef]

7. Turtiainen, M.; Miina, J.; Salo, K.; Hotanen, J. Modelling the coverage and annual variation in bilberry yield in Finland. Silva Fenn. 2016, 50, 1-12. [CrossRef]

8. Turtiainen, M.; Miina, J.; Salo, K.; Hotanen, J. Empirical prediction models for the coverage and yields of cowberry in Finland. Silva Fenn. 2013, 47, 1005. [CrossRef] 
9. Tahvanainen, V.; Miina, J.; Kurttila, M.; Salo, K. Modelling the yields of marketed mushrooms in Picea abies stands in eastern Finland. For. Ecol. Manag. 2016, 362, 79-88. [CrossRef]

10. Miina, J.; Hotanen, J.; Salo, K. Modelling the abundance and temporal variation in the production of bilberry (Vaccinium myrtillus L.) in Finnish mineral soil forests. Silva Fenn. 2009, 43, 577-593. [CrossRef]

11. Martínez-Peña, F.; de-Miguel, S.; Pukkala, T.; Bonet, J.A.; Ortega-Martínez, P.; Aldea, J.; Martínez de Aragón, J. Yield models for ectomycorrhizal mushrooms in Pinus sylvestris forests with special focus on Boletus edulis and Lactarius Group deliciosus. For. Ecol. Manag. 2012, 282, 63-69. [CrossRef]

12. Tomao, A.; Bonet, J.A.; Martínez de Aragón, J.; de-Miguel, S. Is silviculture able to enhance wild forest mushroom resources? Current knowledge and future perspectives. For. Ecol. Manag. 2017, 402, 102-114. [CrossRef]

13. Krebs, C.J.; Boonstra, R.; Cowcill, K.; Kenney, A.J. Climatic Determinants of berry crops in the boreal forest of the Southwestern Yukon. Botany 2009, 87, 401-408. [CrossRef]

14. Coudun, C.; Gégout, J. Quantitative prediction of the distribution and abundance of Vaccinium myrtillus with climatic and edaphic factors. J. Veg. Sci. 2009, 18, 517-524. [CrossRef]

15. Ohenoja, E. Effect of Weather Conditions on the Larger Fungi at Different Forest Sites in Northern Finland in 1976-1988; University of Oulu: Oulu, Finland, 1993; p. 69.

16. Krebs, C.J.; Carrier, P.; Boutin, S.; Boonstra, R. Mushroom crops in relation to weather in the Southwestern Yukon. Botany 2008, 86, 1497-1502. [CrossRef]

17. Martinez de Aragón, J.; Bonet, J.A.; Fischer, C.R.; Colinas, C. Productivity of ectomycorrhizal and selected edible saprotrophic fungi in pine forests of the Pre-Pyrenees Mountains, Spain: Predictive equations for forest management of mycological resources. For. Ecol. Manag. 2007, 252, 239-256. [CrossRef]

18. Alfranca, O.; Voces, R.; Diaz-Balteiro, L. Influence of climatic and economic variables on the aggregated supply of a wild edible fungi (Lactarius deliciosus). Forests 2015, 6, 2324-2344. [CrossRef]

19. Diaz-Balteiro, L.; Alfranca, O.; Voces, R. Market of Lactarius deliciosus. Modelling the supply in Spain. Itea-Informacion Tecnica Economica Agraria 2013, 109, 370-389.

20. Turtiainen, M.; Salo, K.; Saastamoinen, O. Variation of yield and utilisation of bilberries (Vaccinium myrtillus L.) and cowberries (V. Vitis-idaea) in Finland. Silva Fenn. 2011, 45, 237-251.

21. Salo, K. Valtakunnalliset marja- ja sienisatoennusteet. In Tapion Taskukirja, 24th ed.; Hyvämäki, T., Ed.; Metsälehti Kustannus: Helsinki, Finland, 2002; pp. 283-284.

22. Marshall, A. Principles of Economics, 8th ed.; Macmillian and Co.: London, UK, 1890; p. 627.

23. Rubinstein, A. Lecture Notes in Microeconomic Theory, 2nd ed.; Princeton University Press: Princeton, NJ, USA, 2006; p. 150.

24. Voces, R.; Diaz-Balteiro, L.; Alfranca, O. Demand for wild edible mushrooms. The case of Lactarius deliciosus in Barcelona (Spain). J. For. Econ. 2012, 18, 47-60. [CrossRef]

25. European Commission. EU Countries and the Euro. Available online: https://ec.europa.eu/info/businesseconomy-euro/euro-area/euro/eu-countries-and-euro_en (accessed on 11 March 2019).

26. Baek, J.H.; Lee, Y.J. A study on the supply and demand of mushroom. Korean J. Food Mark. Econ. 2003, 20, 109-121.

27. Eurostat: Database. Available online: https:/ec.europa.eu/eurostat/data/database (accessed on 10 April 2018).

28. Rantanen, P.; Valkonen, J. Ulkomaalaisten Marjanpoimijoiden Ja Suomalaisen Maaseudun Kohtaaminen. Maaseudun Uusi Aika 2013, 21, 85-90.

29. Rantanen, P.; Valkonen, J. Ulkomaalaiset Metsämarjanpoimijat Suomessa; Ministry of Foreign Affair: Helsinki, Finland, 2011; p. 84.

30. Tikkanen, I. Challenges in the Supply and Consumption of Wild Berries in Finland. Available online: http://www.saunalahti.fi/irmtikka/WildBerriesIBFRA2014Rovaniemi2015.pdf (accessed on 20 June 2018).

31. Venäläinen, A.; Tuomenvirta, H.; Pirinen, P.; Drebs, A. A Basic Finnish Climate Data Set 1961-2000-Description and Illustration; Finnish Meteorological Institute: Helsinki, Finland, 2005.

32. Raatikainen, M. Syötävien Luonnonmarjojemme Sadoista Ja Poiminnasta; Academia Scientiarum Fennica: Helsinki, Finland, 1983-1984; pp. 135-158.

33. Wallenius, T.H. Yield variations of some common wild berries in Finland in 1956-1996. Ann. Bot. Fenn. 1999, 36, 299-314.

34. Snowdon, P. A Ratio Estimator for bias correction in logarithmic regression. Can. J. For. Res. 1991, 21, 720-724. [CrossRef] 
35. Parladé, J.; Martinez-Peña, F.; Pera, J. Effect of forest management and climatic variables on the mycelium dynamics and sporocarp production of the ectomycorrhizal fungus Boletus edulis. For. Ecol. Manag. 2017, 390, 73-79. [CrossRef]

36. Sievänen, T.; Pouta, E.; Neuvonen, M. Participation In Mushroom Picking In Finland; Social Role of Forests for Urban Population: Forest Recreation, Landscape, Nature Conservation, Economic Evaluation and Urban Forestry; Japan Society of Forest Planning Press: Niigata, Japan, 2004; pp. 122-137.

37. Salo, K. Valtakunnalliset marja-ja sienisatoennusteet. In Metsä. Monikäyttö Ja Ekosysteemipalvelut; Salo, K., Ed.; Fluke Corporation: Hauppauge, NY, USA, 2015; pp. 128-130.

38. Teräs, I. Mustikan Ja Puolukan Pölyttäjät Etelä-Suomessa. Finn. For. Res. Inst. Res. Pap. 1983, 90, 59-65.

39. Raatikainen, M.; Pöntinen, M. Puolukkasadon Ennustamisesta. Finn. For. Res. Inst. Res. Pap. 1982, 90, $104-115$.

40. Hall, I.V.; Aalders, L.E.; McRae, K.B. Lowbush blueberry production in Eastern Canada as related to certain weather data. Can. J. Plant Sci. 1982, 62, 809-812. [CrossRef]

41. Ristioja, A. Toimialaraportti: Luonnontuoteala, Kevät 2018; Työ- ja elinkeinoministeriö: Helsinki, Finland, 2018; p. 48.

42. Peltola, R.; Hallikainen, V.; Tuulentie, S.; Naskali, A.; Manninen, O.; Similä, J. Social licence for the utilization of wild berries in the context of local traditional rights and the interests of the berry industry. Barents Stud. 2014, 1, 24-49.

(C) 2019 by the authors. Licensee MDPI, Basel, Switzerland. This article is an open access article distributed under the terms and conditions of the Creative Commons Attribution (CC BY) license (http://creativecommons.org/licenses/by/4.0/). 